Tér és Társadalom 22. évf. 2008/4. 1-20. p.

Tér és Társadalom

XXII. évf. 2008

4: $1-20$

\title{
ÚJRAIPAROSODÁS A NAGYVILÁGBAN ÉS MAGYARORSZÁGON
}

\section{(Reindustrialization in the World and in Hungary) \\ BARTA GYÖRGYI - CZIRFUSZ MÁRTON - KUKELY GYÖRGY}

Kulcsszavak:

ủjraiparosodás delokalizáció dezindusztrializáció ipar külfóldi müködőtỏke

Az ipar világméretü munkamegosztásában napjainkban is gyors átrendezódési folyamatok mennek végbe. Tanulmányunk a dezindusztrializáció, a delokalizáció, az újraiparosodás és az iparosodás fogalmait és térségtípusait mutatja be. Külön hangsúlyt fektetünk Magyarország rendszerváltás utáni ipari fejlỏdési pályáján keresztül az ủjraiparosodás értelmezésére.

\section{Bevezetö}

2008-ban a Kolozsvár melletti Nemeszsukra költözött az eddig Bochumban müködố Nokia-gyár. Alapjában véve ez az esemény is beleillik abba a delokalizációs trendbe, amely szinte mindennapossá vált az elmúlt évtizedekben Európában. Ebben az esetben viszont a külföldi töke keletebbre költözése mellett arról is szó van, hogy a határainkhoz közel egy új ipari-technológiai központ, és akár egy új kelet-európai növekedési pólus körvonalai bontakozhatnak ki.

Az ugyancsak német Schaub Lorenz International, egy plazma- és LCD-TV gyártással foglalkozó vállalat, Kínából a dél-olaszországi Nolába teszi át a székhelyét a nemrégiben megjelent hírek szerint (Pressetext 2008). Ugyancsak Kínából költözött vissza Magyarországra a vezeték nélküli telefonokat összeszerelő francia cég, a Robust Plastik Assembling (Hunya-Sass 2006). Ezeket az eseteket akár ,visszaköltözésnek", a delokalizáció irányváltozásának is tekinthetjük.

A folyamatok nem egyértelmủ voltát két, egymásnak némileg ellentmondó hír segítségével illusztrálhatjuk: egyikük mintegy 150 ezer munkahely megszüntetésével járó jelentős leépítést prognosztizál a német gazdaság egyik húzóágazatának számító autóiparban, Kelet-Európába és Ázsiába költöztetve az autógyárak (Volkswagen, Mercedes, BMW, Porsche, Opel) termelésének jelentös részét (Dudenhöffer 2008). A Spiegel egyik februári számában (Reiermann 2008) viszont arról írnak, hogy megkezdődött a német ipar reneszánsza, melynek középpontjában a gépipar áll. Ebben az évben, Németországban mintegy 300 ezer ủj munkahely létrehozását jósolják a gazdasági szakemberek, melynek egyharmada az iparban fog megvalósulni. $\mathrm{Az}$ innovatív német gépipar termék- és szolgáltató csomagokat, komplett termelési láncokat exportál az USA-ba; kulcsra kész acélmúveket, gépgyártó sorokat Kinába és 
Barta Györgyi - Czirfusz Márton - Kukely György: Újraiparosodás a nagyvilágban és

Magyarországon. - Tér és Társadalom, 22. 2008. 4. 1-20. p.

\section{Barta Györgyi-Czirfusz Márton-Kukely György TÉT XXII. évf. 2008 - 4}

Indiába. A német ipari export jelentósen növekedett az elmúlt évtizedekben, a gépgyártás, az autóipar és a vegyipar termelésének több mint a felét külföldön értékesítik.

Nem kétséges, eröteljes átrendeződés megy végbe az ipar világméretủ munkamegosztásában. A dezindusztrializáció és a delokalizáció egymással összefüggő folyamatai jelenleg is zajlanak.

A nemzetközi szakirodalomban újonnan jelent meg a reindusztrializáció fogalma, melynek magyar fordítása újraiparosodás, illetve újraiparositás ${ }^{l}$. E fogalom tartalmi magyarázata viszont mindezidáig eléggé ködös maradt. Vajon ez a korábbi iparral összefüggő folyamatok - az ipar leépülése és a gyárak, ágazatok elköltözése, áttelepülése más térségekbe - megfordulását jelenti? Vagy inkább csak az ipar által elhagyott térségek, települések, épületek újra ipari funkcióval történő megtöltésére vonatkoznak? Milyen új ipari tevékenységröl van szó, talán az elköltözött, eltünt szakmák újraélesztéséről? És, ha mindez így van, akkor milyen mozgatóerö képes megfordítani a korábbi folyamatokat?

Tanulmányunk célja, hogy eligazodjunk ebben a „kavalkádban”, és megpróbáljunk választ adni arra, hogy (mi) mit nevezünk újraiparosodásnak, és ez mely térségeket jellemzi elsösorban. Nem könnyü a feladat, elsősorban azért, mert jelenleg is intenziv mozgásban van az ipar, de azért is, mert a hiányos és sokszor nem kompatibilis adatokat igen átgondoltan kell kezelnünk. Például közel sem mindegy, hogy mit választunk vizsgálatunk kiindulási időszakának, illetve, hogy milyen földrajzi egységekre koncentrálunk.

Vizsgálódásunk középpontjába az újraiparosodảs bemutatását helyeztük. Az újraiparosodás - véleményünk szerint - a globális ipari átrendeződés és fejlődés egyik részfolyamata, amelynek tartalmát egyrészt a nemzetközi tendenciák, másrészt a lokális sajátosságok formálják. Nem ellentmondás tehát, hogy a szakirodalom a helyi specialitásoknak megfelelöen más és más tartalommal tölti meg ezt a fogalmat.

Tanulmányunk elsô része az újraiparosodás fogalommagyarázatával, második része a nemzetközi, míg a harmadik része a magyarországi újraiparosodással foglalkozik.

\section{Az újraiparosodás fogalma és területi folyamatai}

Évtizedeken keresztül az érdeklödés középpontjában állt a dezindusztrializáció (angolul de-industrialisation, franciául désindustrialisation), mint a posztindusztriális átalakulás jellemző folyamata, amely alatt azt értjük, hogy az ipar jelentősége, részaránya csökkenni kezd a gazdasági szerkezetben, illetve, hogy az ipari munkahelyek száma abszolút és relatív értelemben - vagyis a foglalkoztatottak száma és részaránya a foglalkozási szerkezetben - visszaesik. A dezindusztrializációval párhuzamosan tercierizálódás, vagyis a szolgáltató szektor megerősödése megy végbe. Ez a folyamat a fejlett országokra vonatkozott - vonatkozik elsősorban, bár a fejlödö országokban is megjelenik (Manzagol 1993).

Az 1980-as évek közepétöl-végétöl - föleg a nyugat-európai szakirodalomban egyre gyakrabban említik az újraiparosodás (reindusztrializáció) folyamatát. 
Barta Györgyi - Czirfusz Márton - Kukely György: Újraiparosodás a nagyvilágban és

Magyarországon. - Tér és Társadalom, 22. 2008. 4. 1-20. p.

TÉT XXII. évf. 2008 - 4

Újraiparosodás a nagyvilágban és ...

$\mathrm{Az}$ újraiparosodás azt a képzetet kelti, mintha egy jól ismert folyamat - a tercierizálódás - megállna, sőt, visszafordulna. Vagyis az ipar a korábban elvesztett terét foglalná vissza.

Korántsem erről van szó!

Véleményünk szerint, az újraiparosodás összetett folyamat, amelynek különböző elemei vannak:

- A technológiai fejlódés eredményeképpen új - az információs technológiai eszközök előállitásával foglalkozó - iparágak jelentek meg a gazdaságban. Az információs és kommunikációs technológia (IKT) egy része a statisztika szerint a feldolgozóiparba sorolódik. Ezt akár az ,új gazdaság” fogalmához kötôdve „új iparnak" is nevezhetnénk. Az IKT más része - az információs és kommunikációs technológiai szolgáltatások - viszont a tercier tevékenységhez tartozik. (Az információs gazdaságot természetesen tágabban is lehet értelmezni: magában foglalja azt az új technológiát, amely gyökeresen áthatja a gazdaság/ipar többi tevékenységét is, sőt, lehetővé teszi a gazdasági/ipari tevékenység növekvő fizikai és földrajzi fragmentálódását, vagyis alapvetően hozzájárul a gazdaság/ipar térbeli átrendezỏdéséhez [Nagy 2002; CsatáriKanalas 2003; Jakobi 2007]).

- Az ipari szerkezetváltás korábbi folyamata is folytatódik egyszersmind: a fejlödés során a nagyobb hozzáadott értéket termelő ágazatok kiszorítják a kisebb hozzáadott értékủ ágazatokat. Vagyis a jármüipar, a gyógyszeripar, az elektronika stb. egyre nagyobb súlyú a fejlett ipari szerkezetben; visszaszorul, sốt nem ritkán el is tünik a tömegtermelö könnyüipar, a vas- és acélipar, az építőanyag-ipar, sôt az élelmiszeripar is.

- A gazdasági/ipari átstrukturálódáshoz tartozik a bonyolultabb tevékenységre, a korszerü, high-tech termékek gyártására, illetve a stratégiai elemek erősítésére való törekvés. Az újraiparosodás lényege a növekvő termelékenység, amely egyaránt köszönhető az új technológiának és az ágazati, tevékenységi, illetve termékszerkezeti változásoknak.

Az újraiparosodás egyaránt jelenti tehát új ágazatok, tevékenységek, termékek megjelenését ott, ahol eddig ilyesmivel nem foglalkoztak. Egyuittal jelenti azt a szerkezeti változást, amikor tradicionális ipari tevékenységek megszũnnek vagy jelentösen visszaszorulnak, és helyüket más ipari tevékenységek veszik át.

$\mathrm{Az}$ újraiparosodás folyamatának mérése felveti a kérdést: a teljesítményt vagy a munkahelyek számát vegyük-e alapul? Az abszolút változást vagy a struktúrában elfoglalt részarány változását mérjük? Ez korántsem csak technikai kérdés. Egyrészt a munkahelyek tömeges megszủnése, gyárak bezárása, sôt, egyes ipari ágazatok eltünése súlyos szociális kérdés, még akkor is, ha az országos mutatók összességében növekvő foglalkoztatást mutatnak. Hiszen nem ugyanazok és nem ugyanott váltanak munkahelyet. Másrészt, ipari kultúrák tünhetnek és tűnnek el egyes, akár országoknál is nagyobb régiókból. Az EU megkülönböztetett mezögazdasági politikájának egyik magyarázata éppen az, hogy fenn kell tartani Európa egész térségében a 
Barta Györgyi - Czirfusz Márton - Kukely György: Újraiparosodás a nagyvilágban és Magyarországon. - Tér és Társadalom, 22. 2008. 4. 1-20. p.

\section{Barta Györgyi - Czirfusz Márton - Kukely György TÉT XXII. évf. 2008 『 4}

mezögazdasági kultúrát... de mi van az ipari kultúrával? Vajon ez nem tartozik az Európai Unió prioritásai közé? Mindez azt tükrözi, hogy az ipari munkahelyek, az ipari foglalkoztatás az ủjraiparosodás érzékeny - a közvélemény számára legfontosabb - tartalmi eleme. Az viszont kétségtelen, hogy a gazdasági/ipari szerkezetváltás a fejlỏdés talán legfontosabb eszköze, módja. (A termelékenység növekedése bekövetkezhet annak révén is, hogy csökken a foglalkoztatás). Joggal állítható, hogy a korábbi évszázadok során is ágazatok, termékek tüntek el a gazdaságból. Miért ragaszkodnánk akkor most az egyes, a gazdaságokból kiszoruló ágazatokhoz, termékekhez? Választás helyett inkább kompromisszumot ajánlunk: elemzésünkben fenntartjuk mindkét - a foglalkoztatást és a termelést is figyelembe vevő - megközelítést.

Az iparban zajló folyamatok új nemzetközi munkamegosztást alakitanak ki. A világ nagyrégiói annak révén is jellemezhetők, hogy milyen - iparhoz köthetö - folyamatok mennek végbe térségük gazdaságában.

Területi szempontból térségeinket a következő föbb csoportokba soroltuk:

- Ahol meghatározó az ipari tevékenység visszaszorulása és elköltözése az ország gazdaságából, vagyis az olyan gazdaságok, amelyeket a dezindusztrializáció és az ipari delokalizáció jellemez elsősorban. Ezekben a gazdaságokban is jelentős ipari szerkezeti átalakulás ment végbe: a korábbi tradicionális, alacsonyabb hozzáadott értéket termelő ágazatok helyét a nagy hozzáadott értékủ iparok, a high-tech, a nagy termelékenységú ágazatok, illetve az új ipar foglalta el. Ezért ebbe a körbe többnyire a fejlett országok tartoznak, ahol az ipari munkahelyek száma drasztikusan csökkent, de az iparból származó GDP akár növekedett is az elmúlt években. Jellemző ezekre az országokra az erôteljes tercierizáció, vagyis az elvesztett ipari munkahelyeket a tercier szektorban megjelenő új foglalkozási lehetöségek pótolták; sőt, ezen országok gazdasági teljesítménye az ipari delokalizációval párhuzamosan számottevően növekedett. Dezindusztrializáció és ipari delokalizáció ment végbe a fejlett nyugati országokban, mely az Amerikai Egyesült Államokban az 1960-as években, NyugatEurópában az 1980-as években kezdödött, és különösen az ezredfordulóra erősödött fel.

- Újraiparosodó térségekben, országokban az egész gazdasági fejlódést meghatározó ipari szerkezetváltás megy (ment) végbe. Új ipari ágazatok (nem csak az IKT körébe tartozóak) jelentek meg, elsősorban a külföldi müködőtőkeberuházásoknak köszönhetően. Az elvesztett tradicionális ipari munkahelyeket az újonnan megjelenő ipar jórészt pótolta, de a lassúbb tercierizáció következtében a foglalkoztatási szint csökkent, és általában növekedett a munkanélküliség. Az ipar termelékenysége látványosan növekedett, sokszor annak ellenére, hogy a high-tech iparnak többnyire az egyszerü, viszonylag kis hozzáadott-értéket termelő részét (az autóiparban például az összeszerelö tevékenységet) helyezték ki a külföldi befektetök ezekbe az országokba. Az is az 
Barta Györgyi - Czirfusz Márton - Kukely György: Újraiparosodás a nagyvilágban és

Magyarországon. - Tér és Társadalom, 22. 2008. 4. 1-20. p.

TÉT XXII. évf. 2008 - 4

Újraiparosodás a nagyvilágban és ...

5

újraiparosodás jellemzője, hogy az ipari beruházások ágazatilag és területileg az ipar korábbi szerkezetéhez képest koncentráltabban, sokszor csak néhány vállalatban összpontosulva jelennek meg. Az újraiparosodás elsősorban egyes nyugat-európai periférikus országokra (İrország, Finnország, Spanyolország), valamint a gyorsabban átalakuló kelet-közép-európai országokra jellemző (Visegrádi országok, Szlovénia, Baltikum).

A gazdasági/ipari válság hosszabban tartó folyamat, vagyis a dezindusztrializációból az újraiparosodás irányába történő váltás lassabban zajlik más kelet-európai országokban (Oroszország, Románia, Bulgária stb.). Ezekben az országokban is elindult az újraiparosodás, de hogy milyen intenzitással milyen változásokat fog eredményezni, még nem lehet tudni.

- A dinamikusan fejlődő országok - mint Kína, a délkelet-ázsiai országok, India, a latin-amerikai országok - jelenleg még az indusztrializáció folyamatát élik, ahol a tradicionális ipari ágazatok is még bővülnek, ugyanakkor megjelent, sőt, dinamikusan fejlödik már az új ipar és a korszerü, high-tech tevékenység is. Ezekben az országokban tömegesen jönnek létre új ipari munkahelyek, mindazonáltal már itt is lassan csökkenö tendenciát mutat az ipar részaránya a foglalkoztatásban.

\section{Delokalizáció, iparosodás és újraiparosodás a világban}

A dezindusztrializáció, az újraiparosodás és az iparosodás fogalmai sem térben, sem időben nem választhatók el egymástól, tiszta típusok nem léteznek. Ezek a folyamatok párhuzamosan zajlanak egy-egy országon vagy régión belül, gyakran még azonos ágazatokban is. A karakterisztikus térségi csoportok elöbbi szerkezetben való áttekintése azonban segíthet tisztázni az újraiparosodás körüli fogalmi vitákat.

A világszintü, valamennyi nagyrégiót érintỏ átrendeződési folyamatok nagyságrendjét jól mutatja a világ néhány országát tartalmazó adatsor (1. táblázat), amelyben elkülöníthetővé válnak az elöbbiekben nevesített térségtípusok is. A fejlett világ egyes országaiban már az 1960-as, 1970-es évektöl is jelentösen csökkent, vagy stagnált az ipari foglalkoztatottak száma, illetve az összes foglalkoztatottakon belüli aránya. Ehhez a csoporthoz csatlakozott 1990 után a kelet-ázsiai térség néhány országa (például a táblázatban szereplö Dél-Korea). 1990 után jelentős visszaesés történt a volt szocialista országokban is, de egyes országokban az 1990-es évek közepétöl, máshol időben eltolva, az ezredforduló után az ipari munkahelyek száma újra emelkedni kezdett. ${ }^{2}$ A harmadik térségtípus az iparosodás jellemzőit mutatja: Európa határán ide tartozik Törökország, de hasonlóan nagy ütemü és több milliónyi új ipari munkahelyet eredményező folyamatok rajzolódnak ki Kelet-Ázsiában és Latin-Amerikában is. Ezeket a térségtípusokat mutatjuk be a következőkben néhány jellegzetes országot, példát kiemelve. 
Barta Györgyi - Czirfusz Márton - Kukely György: Újraiparosodás a nagyvilágban és Magyarországon. - Tér és Társadalom, 22. 2008. 4. 1-20. p.

6 Barta Györgyi-Czirfusz Márton - Kukely György TÉT XXII. évf. 2008 - 4

\section{TÁBLÁZAT}

Ipari foglalkoztatottak száma a világ néhány országában (ezer fö)

(Industrial Employment in Selected Countries of the World - in Thousands)

\begin{tabular}{|c|c|c|c|c|}
\hline Ország & 1985 & 1995 & 2005 & $\begin{array}{c}\text { változás } \\
1995- \\
2005 \\
\text { között }\end{array}$ \\
\hline \multicolumn{5}{|c|}{ Dezindusztrializálódó országok } \\
\hline Japán & 20250 & 21670 & 17750 & -3920 \\
\hline Németország & 10684 & 13003 & 10849 & -2154 \\
\hline Egyesült Államok & 30048 & 29984 & 28074 & -1910 \\
\hline Nagy-Britannia & 8430 & 6951 & 6224 & -727 \\
\hline Dél-Korea & 4415 & 6827 & 6137 & -690 \\
\hline Franciaország & 6768 & 5782 & 5514 & -268 \\
\hline Svájc & 1194 & 1133 & 993 & -140 \\
\hline Svédország & 1283 & 1033 & 939 & -94 \\
\hline \multicolumn{5}{|c|}{ Újraiparosodó országok } \\
\hline Spanyolország & 3377 & 3769 & 5637 & +1868 \\
\hline Írország & 313 & 361 & 537 & +176 \\
\hline Magyarország & 1496 & 1199 & 1265 & +66 \\
\hline Szlovákia & $\ldots$ & 835 & 859 & +24 \\
\hline Finnország & 777 & 571 & 619 & +48 \\
\hline Iparosodó országok & & 1990 & 2005 & $\begin{array}{c}\text { változás } \\
1990- \\
2005 \\
\text { között }\end{array}$ \\
\hline Kína & & 121220 & $* 130480$ & +9260 \\
\hline Indonézia & & 10416 & 17065 & +6649 \\
\hline Mexikó & & 6503 & 11021 & +4518 \\
\hline Brazilia & & 14093 & **17 1757 & +3664 \\
\hline Törökország & & 3599 & 5452 & +1853 \\
\hline
\end{tabular}

Megjegyzés: *2002, **2004

Forrás: OECD ALFS Database; KSH (2004); ILO (2007).

Első csoportunkhoz a dezindusztrializáció térségei tartoznak, ahol egyszersmind általában az ipari tevékenységek más országokba való áthelyezödéséről (delokalizációról) is beszélhetünk. Az ipari foglalkoztatottság csökkenése az Egyesült Államokban kezdődött: a feldolgozóiparban foglalkoztatottak részaránya az 1965-ös csúcsévről (28\%) 2006-ra 10,8\%-ra csökkent. A gazdaságszerkezeti átalakulás viszont itt is egy hullámzó, megélénkülő és lelassuló-visszaforduló szakaszokból álló folyamatot takart. Az ipari munkahelyek száma nagyjából változatlan maradt 1970 és 1994 között (Rowthorn-Ramaswamy 1997), ám közel 3 millió fövel csökkent 2000 után (Bureau of Labor Statistics 2008). 
Barta Györgyi - Czirfusz Márton - Kukely György: Újraiparosodás a nagyvilágban és Magyarországon. - Tér és Társadalom, 22. 2008. 4. 1-20. p.

TÉT XXII. évf. 2008 - 4

Újraiparosodás a nagyvilágban és ...

Nyugat-Európában a folyamat később indult, és nem is volt olyan gyors ütemü, mint az Egyesült Államokban. 1970 és 2005 között az EU-15 tagállamok körében az ipar súlya a foglalkoztatásban a legtöbb esetben 10-20 százalékponttal csökkent. 1995 és 2005 között a csökkenés abszolút értékben Németországban a kétmillió föt, Nagy-Britanniában a hétszázezer föt, Franciaországban a kétszázötvenezret is meghaladta. A dezindusztrializációs folyamatok megítélésének nem egyértelmủ voltát jól mutatja, hogy az értéktermelésben - szemben a foglalkoztatással - az ipar részaránya nem változott a termelékenység növekedése miatt (Haahr-HansenAndersen 2006). Összességében tehát a fejlett térségekben a gazdaság olyan módon alakult át, hogy a kisebb hozzáadott értékủ, alacsonyabb termelékenységü ágazatokat, termelést felváltották a termelékenyebb ágazatok. Ebből pedig az országok gazdasága és társadalma egyértelmủen profitált. Igaz ez annak ellenére, hogy Nyugat-Európában a megszünő ipari munkahelyekröl szóló vállalati delokalizációs döntések bejelentését legtöbb esetben a közvélemény élénk elutasítása kíséri.

A kelet-közép-európai térség átmenetet képez az első (dezindusztrializációs) és a harmadik (iparosodó) csoport között, jellegzetes, ám a nyugat-európaitól eltérö ủjraiparosodási folyamatokat mutatva. A piacgazdasági átmenet során megszủnỏ tradicionális ipari munkahelyeket - a nyugat-európai példával szemben - az 1990-es évtizedben nem tudta pótolni a szolgáltató szektor bővülése. Viszont a felszabadult volt ipari munkaerő munkaerö-piaci szempontból is lehetöséget adott az 1990-es évek közepétől (Oroszországban és más FÁK-tagállamokban később) felgyorsuló újraiparosodásra, döntően nyugat-európai müködötőke-befektetések révén. Az ipari foglalkoztatottak számának bővülése a Visegrádi országok körében Magyarországon már 1996-tól megindult, Csehország és Szlovákia 2000-töl, Lengyelország 2003-tól kapcsolódott be. Az ezredforduló után néhány országban (Csehországban, Magyarországon) rövid, két-három éves stagnáló-visszaeső átmeneti időszak következett be az ipari munkahelyek számának változásában, amelyet a legfrissebb 2006-os adatok alapján valóban átmenetinek tarthatunk. Hasonló folyamatok mentek végbe az Európai Unió nyugati perifériáján, Írországban, ám itt a döntöen az Egyesült Államokból érkező befektetések már az 1990-es évek elejétól új lendületet vettek (Breathnach 1998).

A nyugatról keletre történő átrendeződést alátámasztják a makroszintủ adatok (foglalkoztatottak száma) mellett a vállalati adatok is, melyek szerint a vállalati delokalizáció következtében Nyugat-Európában megszủnt munkahelyek száma az utóbbi években döntően az ipar (és nem a szolgáltatások) különböző ágazataiban magas. Többek között a gép- és villamos gépgyártásban kíséri a nyugat-európai csökkenést kimutatható kelet-közép-európai növekedés. Ugyanakkor mindkét országcsoportban visszaesett a low-tech ágazatokban (élelmiszeripar, textilipar) való foglalkoztatás (Eurofound 2006), ezen szükségletek kielégítése így a jelek szerint például a gyorsan bỏvülő ázsiai térségre hárul. 
Barta Györgyi - Czirfusz Márton - Kukely György: Újraiparosodás a nagyvilágban és

Magyarországon. - Tér és Társadalom, 22. 2008. 4. 1-20. p.

8 Barta Györgyi - Czirfusz Márton - Kukely György TÉT XXII. évf. 2008 @ 4

Harmadik csoportunkból az ipari tevékenységek áthelyeződésének egyik mintaterületét vizsgáljuk részletesen, Kelet-Ázsia iparosodó országait (NIC-országok ${ }^{3}$ ). Az országcsoport elnevezése némileg leegyszerűsítő abban a tekintetben, hogy ezen államok az iparosodás előtt is rendelkeztek kisebb volumenú és zömmel tradicionális iparral, mindazonáltal jól érzékelteti az iparosodás és újraiparosodás közötti különbségeket. A munkamegosztás révén az iparosodás több generációját különböztetik meg a szerzők (NIC1: Tajvan, Szingapúr, Hongkong, Dél-Korea; NIC2: Malajzia, Thaiföld, Indonézia, Fülöp-szigetek; NIC3: Kína, Vietnam), amelyek a gazdasági fejlettség különböző szintjeivel társíthatók (Probáld 1998). A több generációra való felosztás ugyanakkor azt is jelenti, hogy az országok maguk is különböző iparosodási szakaszokon mennek keresztül. Azonban ismét hangsúlyoznunk kell, hogy az ipari átalakulás nem egyszerü, lineáris pályán valósult meg ebben az országcsoportban sem (Bernard-Ravenhill 1995).

A kelet-ázsiai folyamatok elindításában nagy szerepe volt a japán múködötókekivitelnek és a befogadó országokban rendelkezésre álló munkaerőnek. Az átalakulások eredményeképpen kereskedelmi háromszög alakult ki: a kelet-ázsiai ipari termelést irảnyító transznacionális vállalatoknál a megszokottnál erősebb tőke- és technológiai függést írnak le a japán (tajvani, dél-koreai) anyavállalattól, a harmadik pillért pedig Európa és az Egyesült Államok adja, amelyek a késztermékek exportjának legfontosabb céltérségei (Bernard-Ravenhill 1995). Ehhez hasonló kereskedelmi háromszög a kelet-közép-európai térségben nem alakult ki: a késztermékek döntö hányada visszakerül a tőkebefektető nyugat-európai régióba.

Ha az elméletek és a szakirodalom után magukat a számokat vizsgáljuk meg, kizárólag az ipari részarányok elemzése - éppen a foglalkoztatottság általános növekedése miatt - némileg félrevezetỏ lehet. Rowthorn és Ramaswamy tanulmánya (1997) például Hongkonghoz és Szingapúrhoz hasonlóan Tajvanon is dezindusztrializációt említ az elmúlt harminc évben, holott 1975-höz képest 2005-ig 1,2 millió új ipari munkahely jött létre (2. táblázat). Dél-Koreában a foglalkoztatási részarány változatlansága kétmillió új ipari munkahelyet jelentett, a Fülöpszigeteken az aránycsökkenés mellett megkétszereződtek az ipari munkahelyek. Malajziában, Thaiföldön és Indonéziában az arányok változása összhangban van az abszolút értékek növekedésével. A régió egészét nézve az 1975 és 2005 közötti harminc évben nagyfokú átrendeződés ment végbe. Japánban 2,5 millió, Hongkongban félmillió ipari munkahely szünt meg, ezzel szemben a többi államban öszszesen 19,7 millió új jött létre. Vagyis minden megszünt ipari munkahely helyett az országcsoport más tagjainál nyolc újabb létesült. A részarányok stagnálása bizonyos országokban pedig arra is utal, hogy az iparosodás mellett egyáltalán nem elhanyagolható tercier bövülés is végbement. 
Barta Györgyi - Czirfusz Márton - Kukely György: Újraiparosodás a nagyvilágban és Magyarországon. - Tér és Társadalom, 22. 2008. 4. 1-20. p.

TÉT XXII. évf. 2008 - 4

Újraiparosodás a nagyvilágban és...

\section{TÁBLÁZAT}

A feldolgozóipari foglalkoztatás változása néhány kelet-ázsiai országban (1975-2005)

(Changes in the Manufacturing Employment in Selected East Asian Countries, 1975-2005)

\begin{tabular}{lccc}
\hline Ország & & $\begin{array}{c}\text { A feldolgozóipari } \\
\text { munkahelyek } \\
\text { változása (ezer fó) }\end{array}$ & $\begin{array}{c}\text { A feldolgozóipar } \\
\text { arányának változása } \\
\text { a foglalkoztatottak } \\
\text { között (százalékpont) }\end{array}$ \\
\hline Japán & NIC1 & -2469 & $-7,2$ \\
Tajvan & 1208 & $-0,1$ \\
Szingapúr & NIC1 & 266 & $-4,8$ \\
Hongkong & NIC1 & -514 & $-38,0$ \\
Dél-Korea & NIC1 & 2029 & 0,3 \\
Malajzia & NIC2 & 1823 & 12,2 \\
Thaiföld & NIC2 & 4271 & 8,1 \\
Indonézia & NIC2 & 8711 & 5,1 \\
Fülöp-szigetek & NIC2 & 1393 & $-2,2$ \\
\hline
\end{tabular}

Forrás: Timmer-de Vries (2007) adatai alapján saját számítás.

\section{Újraiparosodás Magyarországon}

Magyarországon a szocialista gazdaságpolitikában kiemelt szerepet élvező ipar súlya a szocializmus utolsó éveiben már valamelyest visszaesett, majd a rendszerváltás elsö éveiben válságba került: a nagyvállalatok szétestek, jórészük csődbe jutott és megszünt. Az iparban foglalkoztatottak száma 1994-ig 40\%-kal, félmillió fơvvel csökkent, s visszaesett az ipar GDP-részaránya is. 1992-ben az ipari kibocsátás mindössze az 1989. évi háromnegyedét tette ki (ez megfelel az 1975. évi értéknek). Erőteljes dezindusztrializáció zajlott, mely a rendszerváltás utáni gazdasági térszerkezetre is rányomta bélyegét.

Az 1990-es évek közepétől - bár egyes térségekben a dezindusztrializáció továbbra is jellemzó maradt (pl. Budapest, Borsod-Abaúj-Zemplén megye) - a gyorsuló gazdasági fejlődésben az ipar meghatározó szerepet töltött be. A gazdasági növekedés motorja az újraiparosodás lett. Az ipar fejlódési üteme meghaladta a nemzetgazdaságét, következésképpen a legtöbb tercier ágazatét és természetesen a mezögazdaságét. A fejlődésben igen fontos szerepet játszottak a külföldi müködőtőkebefektetések. Az újraiparosodás új munkahelyek létrehozásával is járt, az ezredfordulóig százezerrel nőtt az ipari foglalkoztatottak létszáma. Az 1990-es évek második felében a gyors gazdasági fejlődésnek az ipar volt a fő hajtóereje, az ipar szerepe a GDP-növekedésben jóval nagyobb volt, mint a GDP-aránya, különösen vidéken. 1994-2001 között a GDP-növekedés egyharmadát (a fövárost leszámítva a 40\%-át) az ipar adta. A beruházások egyre nagyobb hányada az iparban valósult meg (1994: 28\%, 2000: 36\%). Az újraiparosodás elsősorban az észak-dunántúli megyékben 
Barta Györgyi - Czirfusz Márton - Kukely György: Újraiparosodás a nagyvilágban és Magyarországon. - Tér és Társadalom, 22. 2008. 4. 1-20. p.

\section{Barta Györgyi-Czirfusz Márton - Kukely György TÉT XXII. évf. 2008 . 4}

játszott fontos szerepet, ugyanakkor az ország többi (Budapesten kívüli) térségében is a GDP-növekedésben nagyobb szerepe volt az iparnak, mint azt az adott térség gazdasági struktúrájában betöltött szerepe indokolta volna.

Az ezredforduló után döntően a világgazdasági folyamatok begyürüzésének hatására a növekedés dinamizmusa csökkent, a beruházások volumene visszaesett, az ipar vesztett a súlyából, s a foglalkoztatottak létszáma is visszaesett az 1990-es évek közepének szintjére. Ezzel párhuzamosan azonban jelentős struktúraváltás zajlott az iparban: egyes munkaintenzív, alacsony hozzáadott értékủ ágazatok (könnyủipar, egyes elektronikai tevékenységek, kábelköteg-gyártás stb.) leépülttek (megindult a delokalizáció Magyarországról: pl. IBM, Marc, Flextronics), miközben a korábbit meghaladó mértékben emelkedett a termelékenység és növekedett a tökeintenziv és magasabb hozzáadott-értékủ tevékenységek súlya. Az ezredfordulót követö receszsziós évek után 2003-tól az ipar újra a - korábbinál csekélyebb mértékủ - gazdasági fejlődés motorja lett. Az ipari fejlödés visszatért a gyorsabb, bár az 1990-es évek végi ütemet már el nem érỏ sebességre. Az ipar súlya a GDP-ben 2005-ben az 1994-es értéknek felelt meg (25\%). Jelenleg is a feldolgozóipar az egyik legdinamikusabb ágazat a magyar gazdaságban, az export túlnyomó részét adva.

\section{1. ÁBRA}

Az ipari fejlödés különbözö szakaszainak jellemzöi (Characteristics of Stages of Industrial Development in Hungary)
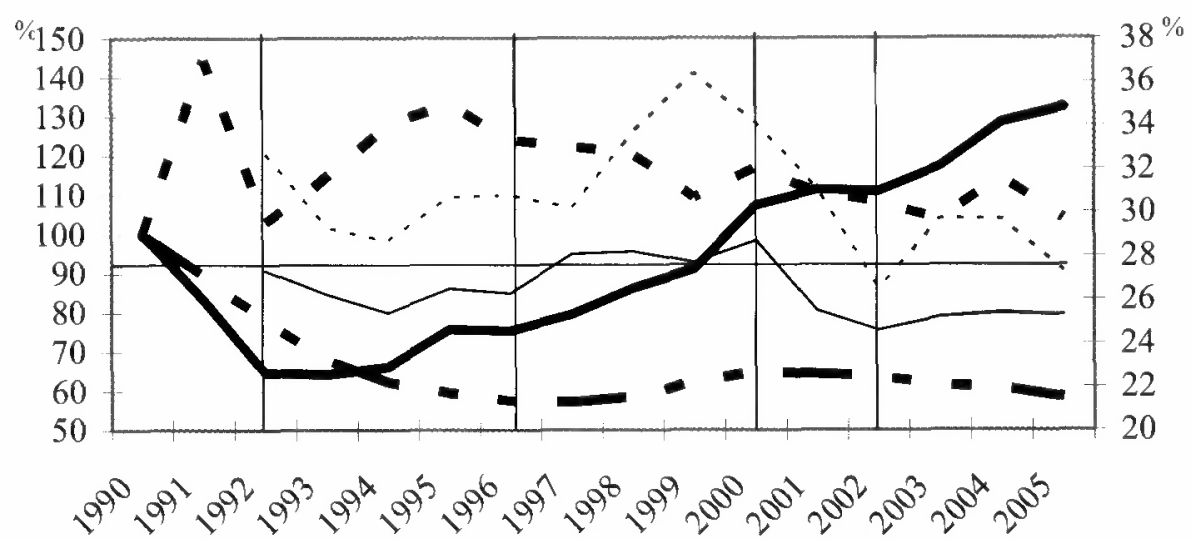

$$
\begin{array}{ll}
\text { - ipari foglalkoztatottak } & \text { ipari termelés } \\
\text { - - - ipar aránya a beruházásokból } & \text { ipar aránya a GDP-ből }
\end{array}
$$

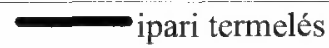

Megjegyzés: a bal oldali skálán jelzett ipari foglalkoztatottak, termelés és beruházások értékei az 1990-es szinthez képesti változást jelzik, a jobb oldali skála mutatja az ipar arányának alakulását a GDP-böl és beruházásokból.

Forrás: KSH. 
Barta Györgyi - Czirfusz Márton - Kukely György: Újraiparosodás a nagyvilágban és

Magyarországon. - Tér és Társadalom, 22. 2008. 4. 1-20. p.

TÉT XXII. évf. 2008 - 4

Újraiparosodás a nagyvilágban és ... 11

A rendszerváltás után tehát az ipar volumene és aránya a termelésben és a beruházások terén is változott, annak dinamikája alapján több fejlődési szakasz rajzolódik ki (1. ábra): visszaesés (általános dezindusztrializáció) (1989-1992), stabilizáció és beruházások (1993-1996), ipari „boom" (általános reindusztrializáció) (1997-2000), megtorpanás (2001-2002), lassú növekedés (2003 után). E szakaszok ipari dinamikáját nagymértékben meghatározták a világgazdasági folyamatok, a privatizáció és az erősödő verseny. Az egyes szakaszokban a nemzetközi vállalati mozgások dinamikája is különbözött.

Az újraiparosodás átalakította az ipar belső szerkezetét. A szocialista gazdaságpolitikában kiemelt szerepet játszó anyag- és energiaigényes nehézipari ágazatok viszszaszorultak, majd az ezredforduló után ugyancsak visszaesett a munkaeröigényes, S az 1990-es évek második felében még felfutó könnyüipar is. A magyar ipar húzóágazataivá - elsősorban a külföldi működőtőke-befektetések révén -a gépiparhoz tartozó, új technológiával termelő, exportorientált, nagy termelékenységü, illetve korábban a magyar ipari struktúrából hiányzó ágazatok kerültek (közúti jảrmügyártás, elektronikai és híradástechnikai ipar). Egyes megyékben már a gépipari ágazatok hozzák létre az ipari GDP kétharmadát (Komárom-Esztergom, Győr-MosonSopron), de egy-két kivételtôl eltekintve (Budapest, Tolna, Csongrád megye) mindenhol a gépipar vált a legfontosabb iparággá (Rédei-Jakobi-Jeney 2002; Kukely 2004). Ez hozzájárult ahhoz, hogy az egyes téregységek ipari struktúrája hasonlóvá vált: a dezindusztrializációs szakaszhoz képest - a Dél-Dunántúl és részben a DélAlföld kivételével - minden régióban az országos iparszerkezettel többé-kevésbé analóg struktúra alakult ki (3. táblázat). A hasonló szerkezeti jelleg azonban az egyes téregységekben igen különböző volumennel, s a külföldi tỏke erősen differenciált jelenlétével párosul.

\section{TÁBLÁZAT}

Az egyes régiók iparszerkezetének az országos átlaghoz képest számitott korrelációs értékei az ipari GDP alapján

(Rank Correlations between National and Regional Industrial Structures Measured by the Industrial GDP)

\begin{tabular}{lcc}
\hline \multicolumn{1}{c}{ Régió } & 1994 & 2005 \\
\hline Közép-Magyarország & 0,91 & 0,93 \\
Közép-Dunántúl & 0,80 & 0,92 \\
Nyugat-Dunántúl & 0,84 & 0,93 \\
Dél-Dunántúl & 0,43 & 0,57 \\
Észak-Magyarország & 0,82 & 0,98 \\
Észak-Alföld & 0,91 & 0,98 \\
Dél-Alföld & 0,82 & 0,84 \\
\hline
\end{tabular}

Forrás: Kiss J. adatai alapján saját számítás. 
Barta Györgyi - Czirfusz Márton - Kukely György: Újraiparosodás a nagyvilágban és Magyarországon. - Tér és Társadalom, 22. 2008. 4. 1-20. p.

\section{Barta Györgyi-Czirfusz Márton-Kukely György TÉT XXII. évf. 2008 — 4}

\section{Az újraiparosodás területi következményei}

A rendszerváltás után az ipari térszerkezet jelentős átalakuláson ment keresztül (Nemes Nagy 1999; Barta 2002; Kiss É. 2002). A korábbi struktúrát egy attól alapvetöen eltéró, új térszerkezet váltotta fel. Az ipari termelés súlypontja nyugat felé tolódott el, a területi egyenlótlenségek növekedtek (2. ábra).

\section{2. ÁBRA}

Az ipari hozzáadott-érték területi különbségei Magyarországon (Spatial Differences of Industrial Gross Value Added on County Level)

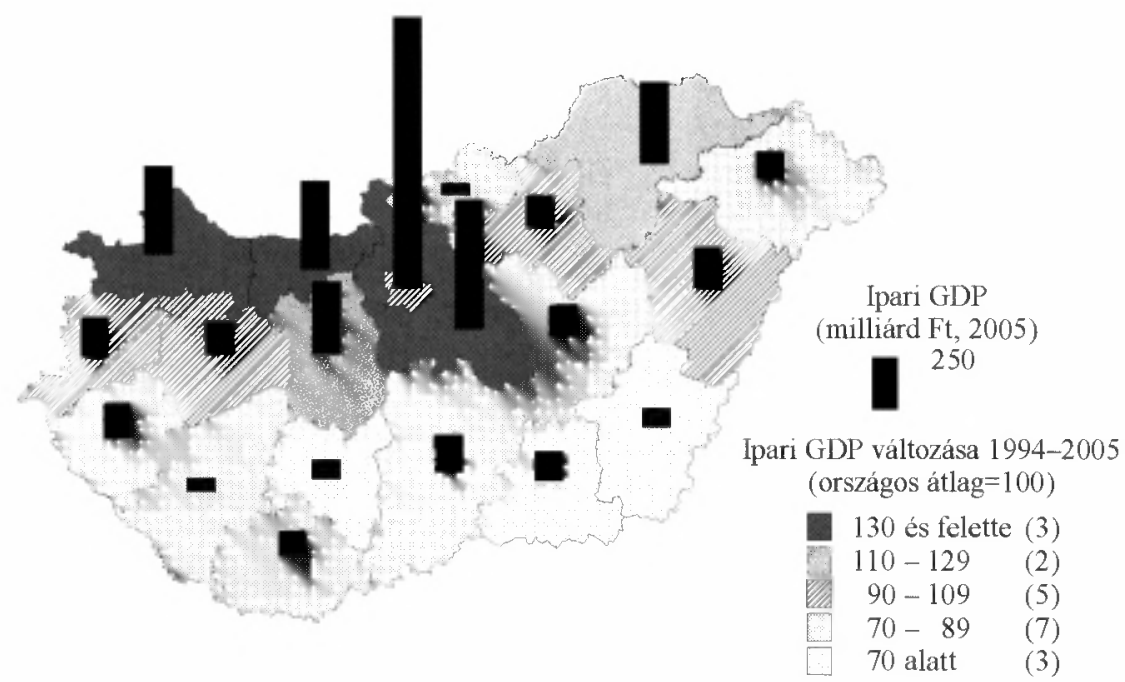

Forrás: Kiss J. adatai alapján saját szerkesztés.

A budapesti ipari koncentráció csökkent, a föváros gazdaságában a tercier ágazatok töltik be a húzószerepet. Ugyanakkor kisugárzó hatása egyre nagyobb térségre terjed ki, a metropolizálódás révén a fơváros és térsége között ủj, a korábbinál szorosabb munkamegosztás alakul ki: az ipari termelés egyre inkább a föváros körüli agglomerációs gyürü területére „vonul ki”, az új ipari beruházások itt koncentrálódnak.

A vidéki térségek differenciálódásában az iparnak meghatározó szerepe volt: a legdinamikusabb észak-dunántúli megyék fejlődésüket elsősorban ipari növekedésüknek köszönhetik. Ugyanakkor a szerkezetváltás problémáival (vagyis többnyire a leépülö iparral) küzdő térségek lemaradása fokozódott. Az ipari jellegü ${ }^{4}$ régiók az 1990-es években a fejlettségi rangsor szélső pólusain helyezkedtek el (Kiss $J$. 1998). Az ezredforduló után azonban Észak-Magyarországon és Észak-Alföldön is előre mozdult az ipar, új ipari beruházások jöttek létre, a dél-magyarországi régiók leszakadása viszont fokozódott (4. táblázat). 
Barta Györgyi - Czirfusz Márton - Kukely György: Újraiparosodás a nagyvilágban és Magyarországon. - Tér és Társadalom, 22. 2008. 4. 1-20. p.

TÉT XXII. évf. 2008 ! 4

Újraiparosodás a nagyvilágban és ... 13

\section{TÁBLÁZAT}

Az ipari bruttó hozzáadott érték területi koncentrálódása (\%)

(Regional Concentration of Industrial Gross Value Added, \%)

\begin{tabular}{llrrr} 
& \multicolumn{1}{c}{ Régiók } & 1994 & 2000 & 2005 \\
\hline Fejlettek & Közép-Mo., Nyugat-Dunántúl, & 60,5 & 66,9 & 68,5 \\
& Közép-Dunántúl & 21,6 & 18,5 & 19,8 \\
Kapaszkodók & Észak-Mo., Észak-Alföld & 17,9 & 14,6 & 11,7 \\
Leszakadók & Dél-Dunántúl, Dél-Alföld & 100,0 & 100,0 & 100,0 \\
& Összesen & & & \\
\hline
\end{tabular}

Forrás: KSH; Kiss János számított adatai alapján.

$\mathrm{Az}$ ủjraiparosodásban meghatározó ágazatok között a nagy termelékenységű, exportorientált, a külföldi tỏke által is preferált tevékenységek játszottak meghatározó szerepet. Ezek területi eloszlása alapján kirajzolódó kép is rámutat az észak-déli megosztottságra: az ipari termelés szempontjából meghatározó megyék az ország északi és középső részében összpontosulnak (5. táblázat).

\section{TÁBLÁZAT}

A megyék sorrendje az ipar egyes jellemzöi alapján (County Rankings Using Different Industrial Indicators)

\begin{tabular}{|c|c|c|c|c|c|c|c|}
\hline & $\begin{array}{l}\text { Húzó- } \\
\text { ágaza- } \\
\text { tok** }\end{array}$ & $\begin{array}{l}\text { Ipari } \\
\text { export }\end{array}$ & $\begin{array}{l}\text { Ipari } \\
K M T\end{array}$ & $\begin{array}{c}\text { Medium- } \\
\text { és high- } \\
\text { tech } \\
\text { ipar** }\end{array}$ & $\begin{array}{c}\text { Termelé- } \\
\text { kenység }\end{array}$ & $\begin{array}{l}\text { Hozzá- } \\
\text { adott- } \\
\text { érték }\end{array}$ & $\begin{array}{c}\text { Sorrend } \\
\text { az összes } \\
\text { mutató } \\
\text { alapján }\end{array}$ \\
\hline 1. & $\begin{array}{l}\text { Komá- } \\
\text { rom-E. }\end{array}$ & $\begin{array}{l}\text { Komá- } \\
\text { rom-E. }\end{array}$ & $\begin{array}{l}\text { Buda- } \\
\text { pest }\end{array}$ & Budapest & $\begin{array}{l}\text { Komá- } \\
\text { rom-E. }\end{array}$ & Budapest & $\begin{array}{l}\text { Komá- } \\
\text { rom-E. }\end{array}$ \\
\hline 2. & $\begin{array}{l}\text { Györ- } \\
\text { Moson- } \\
\text { Sopron }\end{array}$ & $\begin{array}{c}\text { Buda- } \\
\text { pest }\end{array}$ & $\begin{array}{l}\text { Györ- } \\
\text { Moson- } \\
\text { Sopron }\end{array}$ & Pest & $\begin{array}{l}\text { Györ- } \\
\text { Moson- } \\
\text { Sopron }\end{array}$ & Pest & Budapest \\
\hline 3. & $\begin{array}{c}\text { Buda- } \\
\text { pest }\end{array}$ & $\begin{array}{l}\text { Györ- } \\
\text { Moson- } \\
\text { Sopron }\end{array}$ & Pest & $\begin{array}{l}\text { Komá- } \\
\text { rom-E. }\end{array}$ & Fejér & $\begin{array}{l}\text { Komá- } \\
\text { rom-E. }\end{array}$ & $\begin{array}{l}\text { Györ- } \\
\text { Moson- } \\
\text { Sopron }\end{array}$ \\
\hline 4. & Pest & Pest & $\begin{array}{l}\text { Komá- } \\
\text { rom-E. }\end{array}$ & $\begin{array}{c}\text { Györ- } \\
\text { Moson- } \\
\text { Sopron }\end{array}$ & $\mathrm{BAZ}$ & $\begin{array}{l}\text { Györ- } \\
\text { Moson- } \\
\text { Sopron }\end{array}$ & Pest \\
\hline 5. & $\mathrm{BAZ}$ & $\mathrm{BAZ}$ & Fejér & $\mathrm{BAZ}$ & Zala & $\mathrm{BAZ}$ & BAZ \\
\hline
\end{tabular}

Megjegyzés: * iroda- és számítógép, villamosipari gépek, ill. híradástechnikai termékek gyártása, közúti gépjármügyártás; **vegyi anyag és termék, gép és berendezés, iroda- és számítógép, villamosipari gépek, ill. híradástechnikai termék és müszer gyártása, jármügyártás.

Forrás: KSH adatok alapján saját szerkesztés. 
Barta Györgyi - Czirfusz Márton - Kukely György: Újraiparosodás a nagyvilágban és Magyarországon. - Tér és Társadalom, 22. 2008. 4. 1-20. p.

14 Barta Györgyi-Czirfusz Márton - Kukely György TÉT XXII. évf. 2008

$\mathrm{Az}$ ipari termelés abszolút mérete mellett az elmúlt másfél évtizedben az ipari fejlödés dinamikájában is számottevő területi különbségek figyelhetők meg (6. táblázat).

6. TÁBLÁZAT

A megyék sorrendje az ipari termelés növekedési ütemét tekintve

(County Rankings on the Basis of Industrial Production Growth Rates)

\begin{tabular}{|c|c|c|c|c|}
\hline & $\begin{array}{c}\text { 1990-1995 } \\
\text { között * }\end{array}$ & $\begin{array}{c}\text { 1995-2000 } \\
\text { között }\end{array}$ & $\begin{array}{c}2000-2005 \\
\text { között }\end{array}$ & $\begin{array}{c}\text { 1990-2005 } \\
\text { között }\end{array}$ \\
\hline 1 & Vas & Fejér & $\begin{array}{l}\text { Komárom- } \\
\text { Esztergom }\end{array}$ & $\begin{array}{l}\text { Komárom- } \\
\text { Esztergom }\end{array}$ \\
\hline 2 & Fejér & $\begin{array}{l}\text { Györ-Moson- } \\
\text { Sopron }\end{array}$ & Heves & Fejér \\
\hline 3 & Somogy & $\begin{array}{l}\text { Komárom- } \\
\text { Esztergom }\end{array}$ & $\mathrm{BAZ}$ & Vas \\
\hline 4 & Zala & Somogy & Pest & $\begin{array}{l}\text { Györ-Moson- } \\
\text { Sopron }\end{array}$ \\
\hline 5 & $\begin{array}{l}\text { Komárom- } \\
\text { Esztergom }\end{array}$ & Baranya & $\begin{array}{l}\text { Jász-Nagykun- } \\
\text { Szolnok }\end{array}$ & Somogy \\
\hline 6 & Tolna & Zala & Zala & Zala \\
\hline 7 & Hajdú-Bihar & Vas & Bács-Kiskun & Pest \\
\hline 8 & Pest & Pest & Veszprém & Heves \\
\hline 9 & $\begin{array}{l}\text { Bács-Kiskun- } \\
\text { Szolnok }\end{array}$ & $\begin{array}{c}\text { Szabolcs- } \\
\text { Szatmár-Bereg }\end{array}$ & Hajdú-Bihar & Hajdú-Bihar \\
\hline 10 & $\begin{array}{l}\text { Györ-Moson- } \\
\text { Sopron }\end{array}$ & Hajdú-Bihar & Budapest & $\begin{array}{l}\text { Jász-Nagykun- } \\
\text { Szolnok }\end{array}$ \\
\hline
\end{tabular}

Megjegyzés: *1990-1995 között Vas és Fejér megye kivételével az ipari termelés visszaesett, a listán szereplö megyékben kisebb mértékben.

Forrás: Nemes Nagy (1999) és a KSH adatai alapján saját szerkesztés.

Ötéves idószakokat tekintve, alapjaiban különböző kép rajzolódik ki. Ebben szerepet játszott az, hogy egy-egy nagyberuházás nagy befolyással bír egy-egy megye termelésének alakulására, másrészt a növekedés üteme általában azokban a területegységekben magasabb, ahol az ipar kisebb szerepet tölt be, mérete kisebb. Mindössze három olyan megye volt, amely mindhárom szakaszban a legdinamikusabb megyék között található (Komárom-Esztergom, Pest, Zala), s csupán négy (Békés, Csongrád, Nógrád, Szabolcs-Szatmár-Bereg), amely soha nem jelent meg az ipari termelés növekedési rangsorának első felében. Ez egyrészt azt is jelenti, hogy a beruházók új tényezőket (pl. munkaerőt) keresve továbbléptek, s új térségek is bekapcsolódtak az (ủjra)iparosodásba, ami kedvező folyamatként értékelhető. Az újraiparosodás fázisa az egyes területegységekben különbözö időszakban jelentkezett: Györ-Moson-Sopron és Fejér megyében az 1990-es évek közepén, KomáromEsztergom megyében az ezredforduló éveiben, Borsod-Abaúj-Zemplén megyében pedig csak 2003 után. Az ezredforduló után több olyan megye jelent meg a rangsor elsö felében, amely korábban nem volt jelen, köztük néhány olyan, amely tradicioná- 
Barta Györgyi - Czirfusz Márton - Kukely György: Újraiparosodás a nagyvilágban és Magyarországon. - Tér és Társadalom, 22. 2008. 4. 1-20. p.

TÉT XXII. évf. 2008 - 4

Újraiparosodás a nagyvilágban és ... 15

lisan jelentős iparral rendelkezett, de az 1990-es években tartós dezindusztrializáció jellemezte. Az újraiparosodás tehát térben kiterjedt, így e térségekben is struktúraváltást eredményezett.

Ugyanakkor a növekedési ütem mögött az egyes szakaszokban eltérő volumenek jelennek meg: az elmúlt másfél évtized ipari fejlődésében az „ipari boom” időszaka, tehát az 1990-es évek második fele volt a meghatározó, ennek megfelelöen a fejlödési ütemet tekintve is azok a megyék emelkednek ki, amelyek ekkor markáns növekedést produkáltak (bár Komárom-Esztergom fejlödésében az ezredforduló utáni évek a meghatározóak). Kevésbé látványos, de az 1990-es évek végétől folyamatos növekedés zajlott a fövároshoz közeli megyékben (Pest, Heves és Jász-NagykunSzolnok). A szocializmus évei alatt kevésbé iparosodott megyék közül a nyugati határ menti Vas és Zala pozíciója változott lényegesen. ${ }^{5}$ Ugyanakkor néhảny - szocialista ipari fellegvárnak tartott - megye megújulása máig várat magára, például Veszprém vagy Nógrád megye jelenlegi pozíciója messze elmarad a korábbitól, s itt az új beruházások ellenére még a dezindusztrializáció is jellemző.

\section{Az újraiparosodás motorja: a külföldi müködötőke-beruházások}

A rendszerváltás utáni gazdasági növekedés és az újraiparosodás motorjai a külföldi mủködőtőke (KMT)-befektetések voltak és maradtak (Barta-Kukely 2007). A KMT-befektetések segítettek túljutni a gazdasági transzformáció okozta válságon, biztosították a tartós és gyors növekedést, valamint szerepet játszottak a gazdaság modernizálódásában. Mára a külföldi múködőtőke mélyen behatolt a magyar gazdaságba, meghatározó tényezővé vált a gazdaság tulajdoni, ágazati, foglalkozási és területi szerkezetében, a technológiai fejlödés motorja lett. A magyar gazdaság sikeressége, növekvő gazdasági teljesítménye szorosan kapcsolódik a külföldi vállalatok tevékenységéhez. A rendszerváltás óta eltelt másfél évtizedben Magyarország gazdasági növekedését az exportorientált és beruházásvezérelt szektorok, elsősorban a feldolgozóipar ủj elemei határozták meg.

2005-ig több mint 60 milliárd dollár külföldi működőtőke áramlott az országba. A külföldi vállalkozások igen nagy, nemzetközi szinten is kiemelkedö (mindössze Írországgal összevethető) súlyra tettek szert a magyar gazdaságban. A külföldi érdekeltségủ vállalkozások állítják elő a bruttó hozzáadott-értẻk közel felẻt és az export több mint $80 \%$-át. A külföldi beruházások közel fele az iparba, azon belül is elsősorban a feldolgozóiparba irányult. A feldolgozóipari termelés 70\%-át külfôldi tulajdonú cégek állitják elö. 2002 óta azonban a külföldi tőke egyre nagyobb hányada a tercier szektorba áramlik, így - bár továbbra is meghatározó, de - kissé csökken a feldolgozóipar súlya mind a foglalkoztatást, mind az értékesítést, mind a vállalatok saját tökéjét illetôen (7. táblázat). A külföldi tőke az újraiparosodás mellett a tercierizációban is növekvő szerepet játszik. 
Barta Györgyi - Czirfusz Márton - Kukely György: Újraiparosodás a nagyvilágban és Magyarországon. - Tér és Társadalom, 22. 2008. 4. 1-20. p.

16 Barta Györgyi-Czirfusz Márton-Kukely György TÉT XXII. évf. 2008

\section{TÁBLÁZAT}

A feldolgozóipar arányának változása a külföldi müködőtöke-befektetésekben (\%) (Changes in Manufacturing Shares of Foreign Direct Investments, \%)

\begin{tabular}{cccccc}
\hline & $\begin{array}{c}\text { Küllföldi, } \\
\text { feldolgozó- } \\
\text { ipari cégek } \\
\text { aránya }\end{array}$ & $\begin{array}{c}\text { Külföldi, } \\
\text { feldolgozó- } \\
\text { ipari cégek } \\
\text { saját tókéje }\end{array}$ & $\begin{array}{c}\text { külföldi, } \\
\text { külföldi } \\
\text { töke }\end{array}$ & $\begin{array}{c}\text { Külfolddi, } \\
\text { ipari cégek } \\
\text { nettó } \\
\text { árbevétele }\end{array}$ & $\begin{array}{c}\text { feldolgozó- } \\
\text { ipari cégek } \\
\text { létszáma }\end{array}$ \\
\hline 1995 & 17 & 37 & 41 & 41 & 53 \\
2000 & 15 & 38 & 41 & 48 & 59 \\
2002 & 14 & 47 & 47 & 53 & 60 \\
2005 & 13 & 50 & 42 & 50 & 55 \\
\hline
\end{tabular}

Megjegyzés: Legalább 10\% külföldi tulajdonrésszel rendelkezö vállalkozások.

Forrás: KSH Statinfo.

A KMT-befektetések számottevő szerepet játszottak a gazdaság területi szerkezetének formálásában is. A fövárosi térségben ugyan a tercier beruházások a meghatározóak, de így is az összes ipari KMT több mint egyharmada a Középmagyarországi régióba került. Minden más régióban a feldolgozóipar volt a külföldi befektetések fö célpontja. Nyugat- és Közép-Dunántúlon a külföldi befektetések 90\%-a a feldolgozóiparba került, Észak-Magyarországon és Dél-Alföldön emellett az energetikai ipar beruházásai is jelentős tőkét vonzottak. Nincs olyan vidéki régió, ahol az ipari beruházások nem tették ki a külföldi befektetések legalább háromnegyedét! (8. táblázat)

\section{TÁBLÁZAT}

A feldolgozóipar aránya a külföldi müködötöke-befektetésekben 2005-ben (\%) (Manufacturing Share in Foreign Direct Investments on Regional Level, 2005, \%)

\begin{tabular}{lccccc}
\hline & $\begin{array}{c}\text { Külföldi, } \\
\text { feldolgozó- } \\
\text { ipari cégek } \\
\text { száma }\end{array}$ & $\begin{array}{c}\text { Külföldi, } \\
\text { feldolgozó- } \\
\text { ipari cégek } \\
\text { saját tökéje }\end{array}$ & $\begin{array}{c}\text { ebböl: } \\
\text { külföldi } \\
\text { töke }\end{array}$ & $\begin{array}{c}\text { Külföldi, } \\
\text { feldolgozó- } \\
\text { ipari cégek } \\
\text { nettóárbe- } \\
\text { vétele }\end{array}$ & $\begin{array}{c}\text { Külföldi, } \\
\text { feldolgozó- } \\
\text { ipari cégek } \\
\text { létszáma }\end{array}$ \\
\hline Közép- & 8 & 37 & 21 & 29 & 32 \\
$\begin{array}{l}\text { Magyarország } \\
\text { Közép-Dunántúl }\end{array}$ & 24 & 89 & 90 & 88 & 81 \\
Nyugat- & 20 & 90 & 91 & 86 & 81 \\
Dunántúl & & & & & \\
Észak- & 33 & 80 & 74 & 83 & 84 \\
Magyarország & 25 & 76 & 81 & 75 & 83 \\
Dél-Dunántúl & 16 & 86 & 88 & 71 & 82 \\
Észak-Alföld & 23 & 47 & 47 & 56 & 78 \\
Dél-Alföld & 13 & 50 & 42 & 50 & 55 \\
Összesen & & & & & \\
\hline
\end{tabular}

Megjegyzés: Legalább 10\% külföldi tulajdonrésszel rendelkező vállalkozások.

Forrás: KSH Statinfo. 
Barta Györgyi - Czirfusz Márton - Kukely György: Újraiparosodás a nagyvilágban és Magyarországon. - Tér és Társadalom, 22. 2008. 4. 1-20. p.

A külföldi beruházásokon belül az ipar dominanciája minden vidéki régióra jellemző, ám továbbra is a Közép-magyarországi régióban koncentrálódik a külfơldi feldolgozóipari cégek több mint 40\%-a. A három legfejlettebb régióba került az összes külföldi feldolgozóipari beruházás négyötöde, $\mathrm{s}$ az elmúlt évtizedben e térségek súlya még valamelyest nött is (9. táblázat). Tehát a külföldi tókének köszönhetỏ újraiparosodási folyamat a regionális különbségeket tovább fokozta. A vidéki térségek közül különösen az észak-dunántúli megyék profitáltak a külföldi feldolgozóipari beruházásokból, az itt magyarországi székhellyel rendelkezỏ cégek tökeállománya több mint kétszeresen haladja meg a másik négy vidéki régióét.

\section{TÁBLÁZAT}

A külföldi feldolgozóipari cégek regionális struktúrájának változása (\%) (Changes in Regional Structure of Foreign-owned Manufacturing Firms, \%)

\begin{tabular}{|c|c|c|c|c|c|c|c|c|c|}
\hline & \multicolumn{3}{|c|}{$\begin{array}{l}\text { Külföldi tóke a } \\
\text { saját tökéból }\end{array}$} & \multicolumn{3}{|c|}{ Nettó árbevétel } & \multicolumn{3}{|c|}{ Létszám } \\
\hline & 1995 & 2000 & 2005 & 1995 & 2000 & 2005 & 1995 & 2000 & 2005 \\
\hline $\begin{array}{l}\text { Közép- } \\
\text { Magyarország }\end{array}$ & 48 & 39 & 34 & 42 & 28 & 36 & 37 & 30 & 31 \\
\hline Észak-Dunántúl & 31 & 38 & 46 & 33 & 48 & 41 & 32 & 35 & 35 \\
\hline $\begin{array}{l}4 \text { kevésbé fejlett } \\
\text { régió }\end{array}$ & 22 & 23 & 20 & 25 & 24 & 22 & 31 & 36 & 34 \\
\hline $\begin{array}{l}3 \text { legfejlettebb } \\
\text { régió }\end{array}$ & 78 & 77 & 80 & 75 & 76 & 78 & 69 & 64 & 66 \\
\hline
\end{tabular}

Megjegyzés: Legalább 10\% külföldi tulajdonrésszel rendelkezö vállalkozások.

Forrás: KSH Statinfo.

\section{A delokalizáció szerepe az újraiparosodásban}

Az újraiparosodásban meghatározó szerepet játszott a delokalizáció, azaz a fejlett országokból Magyarországra áthelyezett ipari tevékenység. Magyarország a delokalizációs tevékenység nyertesei közé tartozik. A delokalizáció okai között a legfontosabb szerepet az alacsony termelési költségek játsszák, mely különösen a nagy munkaerö-intenzitású tevékenységek s a könnyen exportálható termékek terén érvényesül. Magyarország (s hasonlóan más kelet-közép-európai országok), mint az európai magterülethez közel fekvő, stabil gazdasági-politikai rendszerrel jellemezhetỏ uniós tagország a külföldi vállalatok számára egyre vonzóbbnak bizonyult. Több cég jelentôs beruházást létesített Magyarországon, miközben Európa más térségeiben megszüntette vagy redukálta termelését, vagy adott termék bỏvülỏ piacának ellátásához új magyarországi telephelyet létesített. A magyarországi termelés jelentôs hányada nem a hazai keresletet célozta meg, hanem nyugat-európai piacokra került. Az újraiparosodásban az új befektetések mellett a már jelenlévő vállalatok pótlólagos beruházásai válnak egyre inkább meghatározóvá. Azonban már nemcsak a kapacitások bỏvítése, hanem a termékskála magasabb hozzáadott-értékủ szegmensei 
Barta Györgyi - Czirfusz Márton - Kukely György: Újraiparosodás a nagyvilágban és Magyarországon. - Tér és Társadalom, 22. 2008. 4. 1-20. p.

18 Barta Györgyi-Czirfusz Márton-Kukely György TÉT XXII. évf. 2008 - 4

felé történő eltolódás is egyre jellemzőbb. Az ezredforduló óta a termelésáthelyezés Magyarországról is megindult. Jellemzően az alacsony hozzáadott értékü tevékenységek terén jelent meg a Magyarországról történő kivonulás ${ }^{6}$ (s nemcsak a tradicionális ágazatok, hanem az új ipar területén is), azaz a domináns ủjraiparosodással párhuzamosan, kisebb mértékú dezindusztrializáció is zajlik. A kettő eredójeként lejátszódó technológiai és termék-szerkezetváltás hozzájárul a gazdaság és az ipar fejlödéséhez, a nagyobb hozzáadott értékú termeléshez.

Mindezek a folyamatok jelzik, hogy Magyarország az újraiparosodás egyik jellemző példája, ahol ezek a folyamatok elöször koncentráltan jelentkeznek, majd fokozatosan kiterjednek.

\section{Összegzés}

Tanulmányunkkal azt szeretnénk hangsúlyozni, hogy az újraiparosodás semmiképpen sem jelez valamiféle új trendet a gazdasági fejlödésben. Olyan ismert ipari folyamatok jelenleg is fontos szerepéról számolunk be, amelyek innovativitásuk, illetve térbeli kihatásaik következtében a figyelmet újra az iparra terelték.

Az újraiparosodás - tartalma szerint - két fontos változást jelez:

- Egyrészt a technológiai fejlődéssel új ágazatok jelennek meg (IKT), amelyek részben a feldolgozóipar részét képezik, és az IKT mint új technológia átitatja, innovatívvá teszi a gazdaság/ipar más (tradicionális) ágazatait. (A statisztikusoknak kell megoldani az IKT ipari és szolgáltató kettỏsségének kezelését, amelyre már megoldások is születtek. ${ }^{7}$ ) Az innovatív ipar jelenleg is a gazdasági növekedés meghatározója a fejlett országokban.

- Másrészt átstrukturálódási folyamat megy végbe az iparban, a dezindusztrializációs folyamatban eltủnnek a tradicionális ipar alacsony hozzáadott értékü ágazatai, és helyüket a high-tech vagy más, magasabb termelékenységü ágazatok foglalják el. A korábbi szerkezetváltási folyamatokhoz képest újdonság, hogy ennek legfontosabb mozgatói a multinacionális vállalatok. Külföldi beruházásaik révén korábban nem létezó tevékenységek, és/vagy magasabb termelékenységü, high-tech ágazatok kerülnek a kevésbé fejlett országok gazdaságába.

Megemlítjük, hogy sehol sem zajlottak és zajlanak „tiszta” folyamatok: a dezindusztrializáció, a delokalizáció, az új innovatív ipar és a multinacionális vállalatok ipari beruházásai mindenütt egy időben, egymással párhuzamosan, egymást kiegészítve és keresztezve jelennek meg. Az ipar területi típusait a domináns folyamatok határozzák meg: a fejlett világban az ipar visszahúzódása mellett nagy az innovatív ágazatok jelentősége. A fejlett és a fejlődő világ határán lévő kelet-(közép)-európai országokban a versenyképtelen, túlméretezett szocialista ipar a rendszer összeomlását követően nem bírta a nemzetközi konkurenciát, viszont vonzó terepe lett a fejlett világból származó mủködőtőke-befektetéseknek. Az iparosodó térségekben (NIC) is jelen van az új ipar, az ipar innovatív ágazatai, de emellett a tradicionális ágazatok is tovább bóvülnek. 
Barta Györgyi - Czirfusz Márton - Kukely György: Újraiparosodás a nagyvilágban és

Magyarországon. - Tér és Társadalom, 22. 2008. 4. 1-20. p.

TÉT XXII. évf. 2008 - 4

Újraiparosodás a nagyvilágban és...

$\mathrm{Az}$ újraiparosodás valójában nem is teljesen megfelelő szó e tanulmányban jelzett folyamatok átfogó megnevezésére, mivel nem az iparosodás megállásáról, majd újraindulásáról, és még kevésbé a korábbi trendek visszafordulásáról van szó, hanem egy olyan összetett folyamatról, amely egyrészt ủj, innovatív ipari fejlödésre, másrészt az ipar ágazati és térbeli átstrukturálódására vonatkozik.

\section{Jegyzetek}

${ }^{1} \mathrm{Az}$ újraiparosodás egy többé-kevésbé spontán folyamatot ír le, míg az újraiparosítás politikai beavatkozást állít a középpontba. A tanulmányban mi az elöbbire fókuszálunk.

${ }^{2}$ Az újraiparosodás kezdete sok tényezótól függ. A piacgazdasági átmenet sebessége, a tradicionális (nehéz)ipari ágazatok gazdasági súlya, leépülésének üteme alapvetỏen befolyásolta azt.

${ }^{3}$ A szakirodalomban elterjedt újonnan iparosodott országok (newly industrialized countries) helyett mi az iparosodó megnevezést használjuk. Ezzel az előbbi fogalom (a valóságos folyamatok által nem megerösített) befejezettséget sugalló tartalmát kiküszöböljük, valamint elkerüljük a kis elnevezésbeli különbségekböl (újraiparosodó - újonnan iparosodó) adódó, Kelet-Közép-Európával való esetleges összekeverést.

${ }^{4}$ Ipari jellegünek tekintjük azokat a megyéket, ahol a foglalkoztatottak legalább egyharmada az iparban dolgozik.

${ }^{5}$ A statisztikákban kiemelkedó pozíciókat elérô Somogy nem tekinthetó iparosodott megyének, kedvezö pozícióját elsỏsorban az ország négy megyéjében termelést végzó, de tabi székhelyú Flextronicsnak köszönheti (sőt az ipari GDP alapján Somogy a legkevésbé iparosodott megye).

${ }^{6}$ A textil-, bőr- és cipőiparban 2000 és 2005 között 50 ezerrel csökkent a foglalkoztatottak létszáma, s a külföldi tôke aránya radikálisan redukálódott.

${ }^{7}$ A 2008-ban megújított TEÁOR-ban (A gazdasági tevékenységek egységes ágazati osztályozási rendszere) a statisztikában is önálló nemzetgazdasági ágként jelent meg az Információ és kommunikáció. Ez termeló és szolgáltató tevékenységet is magában foglal, melyeket korábban az ipar, a távközlés, a gazdasági szolgáltatások stb, ágazatokba soroltak.

\section{Irodalom}

Barta Gy. (2002) A magyar ipar területi folyamatai 1945-2000. Dialóg-Campus, Budapest-Pécs.

Barta, Gy.-Kukely, Gy. (2007) The role of foreign direct investments in Hungary's regional development. Moravian Geography Report. 2. 2-12. o.

Bernard, M.-Ravenhill, J. (1995) Beyond Product Cycles and Flying Geese: Regionalization, Hierarchy, and the Industrialization of East Asia. - World Politics. 2. 171-209. o.

Bureau of Labor Statistics (2008) Industries at a glance. Manufacturing: NAICS 31-33. www.bls.gov/iag/manufacturing.htm

Breathnach, P. (1998) Exploring the 'Celtic Tiger' Phenomenon: Causes and Consequences of Ireland's Economic Miracle, - European Urban and Regional Studies. 4. 305-316. o.

Csatári B.-Kanalas I. (2003) Bevezetés. Az információs ágazat súlya a nemzetgazdaságon belül. -- Kanalas I.-Nagy G. (szerk.) Régiók az információs társadalomban. MTA RKK ATI, Kecskemét. 5-7. o.

Dudenhöffer, F. (2008) Autobranche verliert in 10 Jahren 150.000 Jobs. http://www.fhgelsenkirchen.de/fbl l/homepages/dudenhoeffer/duden.html

Eurofound (2006) Restructuring and employment in the EU: Concepts, measurement and evidence. Office for Official Publications of the European Communities, Luxembourg.

Haahr, J.H.-Hansen, M.E.-Andersen, T. (2006) Restructuring in Europe. The Anticipation of Negative Labour Market Effects. Danish Technological Institute.

Hunya G.-Sass M. (2006) Nyer-e Magyarország a termeléskihelyezéssel? - Külgazdaság. 2. 33-53. o.

ILO (2007) Key Indicators of the Labour Market (KILM). Fifth Edition. CD-ROM.

Jakobi A. (2007) Az információs társadalom térbelisége. Regionális Tudományi Tanulmányok. 13. ELTE Regionális Tudományi Tanszék, Budapest. 
Barta Györgyi - Czirfusz Márton - Kukely György: Újraiparosodás a nagyvilágban és

Magyarországon. - Tér és Társadalom, 22. 2008. 4. 1-20. p.

20 Barta Györgyi-Czirfusz Márton - Kukely György $\quad$ TÉT XXII. évf. 2008 - 4

Kiss É. (2002) A magyar ipar térszerkezeti változásai. - Földrajzi Értesitő. 3-4. 347-365. o.

Kiss J. (1998) Az ágazati gazdaságszerkezet szerepe a regionális differenciálódásban Magyarországon. -

Tér és Társadalom. 1-2.138-162. o.

KSH (2004) Nemzetközi Statisztikai Évkönyv. Központi Statisztikai Hivatal, Budapest.

KSH Statinfo adatbázis. Központi Statisztikai Hivatal, Budapest.

Kukely Gy. (2004) Szerkezetváltás a magyar ipar húzóágazatában, a gépiparban. - Földrajzi Értesitőo. 1-2. 93-110. o.

Manzagol, C. (1993) La localisation des activités specifiques. - Bailly, A.-Ferras, R.-Pumain, D. (eds.) Encyclopédie de Géographie. Vol. II. Economica (Suisse) S,A. 507-533. o.

Nagy G. (2002) Nagyvállalati típusok - müködési stratégiák. - Tér és Társadalom. 2. 41-52, o,

Nemes Nagy J. (1999) Elágazó növekedési pályák az ezredvégi Magyarországon. - Nemes Nagy J. (szerk.) Helvek, terek, régiók. - Regionális Tudományi Tanulmányok. 4. ELTE TTK Regionális Földrajzi Tanszék, Budapest. 65 86. o.

OECD Annual Labour Force Statistics (ALFS) Database. http:/stats,oecd.org

Pressetext (2008) Schaub Lorenz verlegt Produktion von China nach Italien. www.pressetext.ch/ pte.mc?pte 080205011

Probáld F. (1998) Ázsia, Ausztrália és Óceánia földrajza. ELTE Eötvös Kiadó, Budapest.

Rédei M.-Jakobi Á.-Jeney L. (2002) Regionális specializáció és a feldolgozóipari tevékenység változása. Tér és Társadalom. 4. 87-108. o.

Reiermann, Ch. (2008) Überraschende Renaissance, - Der Spiegel, 7. 66-67. o. www.spiegel.de/spiegel/ $0,1518,534216,00 \cdot \mathrm{html}$

Rowthorn, R.-Ramaswamy, R. (1997) Deindustrialization - Its Causes and Implications, - Economic Issues. 10. International Monetary Fund, Washington, D. C.

Timmer, M.P.-de Vries, G.J. (2007) A Cross-Country Database For Sectoral Employment And Productivity In Asia And Latin America, 1950-2005. Groningen Growth and Development Centre.

\section{REINDUSTRIALIZATION IN THE WORLD AND IN HUNGARY}

\section{GYÖRGYI BARTA - MÁRTON CZIRFUSZ - GYÖRGY KUKELY}

Rapid change occures recently in the global industrial division of labour, with growing relocation activities after the turn of the millennium. Industry is moving from one country to another; in some cases (such as in the United States and in Western Europe) deindustrialisation, in others industrialisation became a typical process. Developing countries are increasing their shares in global industrial labour and output values, as both the traditional and the new (or high-tech) industries are showing high growth rates. The peripheries of Europe, so as EastCentral-European countries are characterised by reindustrialisation where traditional industries are declining, industrial structure is changing but industry as a sector is leading the economic development further on. In these processes, foreign direct investment and international relocation have a considerable influence. The mentioned distinction (deindustrialisation, industrialisation and reindustrialisation) can be also useful when a country is examined/studied. In this paper, the Hungarian shifts are presented in particular: from the mid-1990s more and more counties show reindustrialisation patterns, most apparently the Western counties. Apart from the regional differences, industry is the key sector in the economic development in the whole country. 